\title{
Reproduction abilities of Ips typographus (L.) (Coleoptera: Curculionidae, Scolytinae) in the stands damaged by the wind in 2013 in the Kościeliska Valley (Tatra National Park)
}

\author{
Wojciech Grodzki ${ }^{1} \bowtie$, Wojciech Gqsienica Fronek ${ }^{2}$ \\ ${ }^{1}$ Forest Research Institute, Department of Mountain Forests, Fredry 39, 30-605 Kraków, Poland, \\ e-mail: W.Grodzki@ibles.waw.pl \\ 2 Tatra National Park, Kuźnice 1, 34-500 Zakopane, Poland
}

\begin{abstract}
At the end of 2013, strong wind destroyed spruce stands on large areas of Kościeliska Valley in Tatra Mts. in Poland. In 2015-2017, 304 bark samples were collected from 106 spruces; $25 \mathrm{~cm} \times 25 \mathrm{~cm}$ large samples were taken from 2 or 4 sections of infested trees in July/August each year. The infestation density, sex ratio, length of maternal galleries, number of progeny and impact of natural enemies were recorded. The infestation density in individual years was $0.79-0.86$ mating chambers per $\mathrm{dm}^{2}$, the average length of maternal gallery $(55.2-56.6 \mathrm{~mm})$ did not differ between years, The average number of progeny per female from 3-year pooled data was 18.22 , the highest in 2015 (27.4) then collapsed to 15.5-16.8. The gallery systems with 2 females, in which the reproduction success was the highest, dominated (62.6\%). The frequency of parasitoids or entomopathogens was very low (2-20\% mortality rate in 19 bark samples). Possible reasons of relatively low reproduction success regardless generally favourable breeding conditions and its collapse after first year, such as high infestation density and low survival rate of larvae because of climatic conditions (drought), are discussed. Taking into account the described population features, very intense tree mortality and mechanisms known from the other wind events, further development of the outbreak can be expected in this area.
\end{abstract}

\section{KeY WORDS}

bark beetles, galleries, progeny, sex ratio, wind damage, population dynamics

\section{INTRODUCTION}

At the end of the 2013, the spruce stands located in western part of Tatra National Park (mostly in the Kościeliska Valley) have been severely affected by strong wind. Large amount of broken or fallen trees, which were processed and removed (active protection zone) or left in the forest (passive protection zone), according to legal regulations, was (at least temporarily) at disposal as breeding material for bark and wood boring insects. Starting from 2015 - the second growing season after the windfall - fast increase in the popula- 
tion level of the spruce bark beetle Ips typographus (L.) and related infestations of standing trees were observed (Grodzki and Gąsienica Fronek 2017). Such opportunity enabled the survey on the reproduction abilities of I. typographus population in the mountain environment offering favourable breeding conditions.

The dynamics of bark beetle populations in Norway spruce stands is dependent on several environmental factors that influence their reproduction capacities and breeding success (Wermelinger 2004). However, the parameters describing the populations, such as the sex ratio, fecundity and mortality, vary in subsequent outbreak phases (Anderbrant 1990; Lobinger 1996; Wermelinger 2002). However, the data on the bark beetle reproduction features, collected during the initial (progressive) outbreak phase, are of great importance for the assessment of the bark beetle outbreak potential and resulting mortality of attacked trees.

The aim of this study was to explore some traits describing the reproduction abilities of spruce bark beetle I. typographus in favourable breeding conditions offered by wind-damaged stands. The data collected in the initial phase of the outbreak might be very useful for the risk assessment by the prediction of beetle populations' dynamics in the next years.

\section{MATERIAL AND MEtHOdS}

In 2015 , a set of 10 small plots (20 trees each) was established in the exposed forest edges around the winddamaged area in the Kościeliska Valley $\left(49^{\circ} 15^{\prime} 17^{\prime \prime}-\right.$ $\left.49^{\circ} 16^{\prime} 20^{\prime \prime} \mathrm{N}, 19^{\circ} 51^{\prime} 36^{\prime \prime}-19^{\circ} 52^{\prime} 19^{\prime \prime} \mathrm{E}\right)$ in the Tatra National Park, at the altitudes between 980 and 1,200 m a.s.l. (Grodzki and Gąsienica Fronek 2017). The numbered trees were examined during 3 growing seasons (2015-2017) in order to determine the spruces recently infested by bark beetles, which actually developed under the bark. The $25 \mathrm{~cm} \times 25 \mathrm{~cm}$ large bark samples were taken from identified infested trees in July/August each year. In the active protection zone of the National Park, the trees were felled and then sampled in four characteristic sections of the trunks: (I) in the tree base, (II) in the midway between the tree and the crown base, (III) under the crown and (IV) in the middle of the crown (Grodzki 2007). In the passive protection zone, where tree felling is not allowed, the samples were tak- en from the sections I and II on standing trees. Bark samples were analysed in the laboratory, where the following parameters were registered from each sample:

- bark thickness with resolution to $1 \mathrm{~mm}$,

- the infestation density on the analysed trees (the number of gallery systems with one to four maternal galleries),

- the share of females in the population colonising trees (the number of mating chambers as the number of males; the number of maternal galleries as the number of females);

- the length of 10 maternal galleries randomly chosen from the systems with 1-4 females (harem size) measured in each analysed bark sample;

- the effective reproduction understood as the number of progeny (eggs and larvae per maternal gallery) in 2016-2017 separately from the systems with 1-4 females (harem size);

- the estimated percentage of individuals parasitised or infected by entomopathogenic fungi.

The statistical data treatment was aimed to test the significance of differences in analysed traits using the nonparametric Kruskal-Wallis (K-W) test, Pearson correlations for gallery length and number of progeny and the Wilcoxon paired rank test for model validation. For processing the data, MSExcel and Statistica 9.0 (StatSoft Inc. 2009) were used.

\section{Results}

During 3 growing seasons, 304 bark samples were collected from 106 spruces: 20 in 2015, 36 in 2016 and 50 in 2017. Samples from 4 sections were collected from 5, 15 and 25 trees, respectively. In total, 3108 gallery systems were analysed: 516 in 2015 (48 sections), 1067 in 2016 (102 sections) and 1525 in 2017 (154 sections).

The average ( \pm standard deviation) infestation density (number of mating chambers per $1 \mathrm{dm}^{2}$ ) calculated from all samples collected was $0.86( \pm 0.31)$ in 2015 , $0.84( \pm 0.36)$ in 2016 and $0.79( \pm 0.46)$ in 2017. If only the data from sections I and II (sampled from all trees) were used, the infestation densities were $0.89( \pm 0.33), 0.82$ $( \pm 0.38)$ and $0.62( \pm 0.43)$, respectively.

The share of females in the population colonising trees was the highest in 2015, reaching $65.7 \%( \pm 4.9)$, then decreasing in the following years: $63.3 \%( \pm 3.7)$ in 
2016 and $60.6 \%( \pm 12.4)$ in 2017 . During 3-year period, there were almost twice as many females than males - the average number of females per 1 male was 1.78.

The average length of maternal gallery produced by one female was $56.6 \mathrm{~mm}( \pm 15.6)$ in $2015,55.2 \mathrm{~mm}$ $( \pm 11.6)$ in 2016 and $55.9 \mathrm{~mm}( \pm 13.8)$ in 2017, with no significant differences between individual years (K-W test: $H(2, \mathrm{~N}=2,562)=1.799, p=0.41)$.

The number of females in a gallery system (the socalled harem size) affected the average length of maternal galleries. In the collected bark samples, the gallery systems with 2 females dominated (62.6\%), those with 1 female were frequent (29.5\%), whilst those with 3 females were relatively rare $(7.8 \%)$. Owing to very low sample size in the class of 4 females ( 6 items), this parameter was analysed in 3 classes only (1-3 females). The average maternal gallery length was the highest in the systems with 1 female and then decreased gradually with increasing number of females (Fig. 1), with statistically significant differences between all 3 classes (K-W test: $H(2, \mathrm{~N}=2,556)=31.65 p<0.001)$. The maternal gallery length was not correlated with the colonisation density.

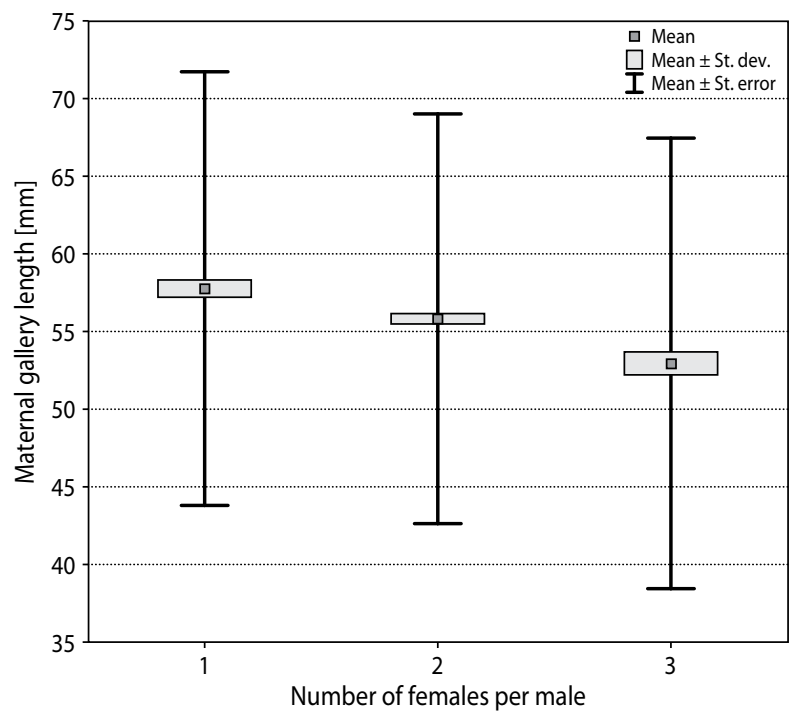

Figure 1. Average length of maternal gallery depending on the number of females in a gallery system

The average number of progeny (understood as the number of eggs and larvae) calculated from 3-year pooled data was $18.22( \pm 8.70)$ and differed between individual years (Fig. 2), reaching $27.40( \pm 8.70)$ in 2015 ,
$15.54( \pm 7.07)$ in 2016 and $16.77( \pm 6.83)$ in 2017, with statistically significant differences between all individual years (K-W test: $H(2, \mathrm{~N}=2,286)=520.27, p<0.001)$. The number of progeny slightly differed depending on the harem size, being the highest $(16.38 \pm 6.71)$ in the systems with 2 females, lower $(16.24 \pm 7.12)$ in those with 1 female and the lowest $(15.29 \pm 7.88)$ in the systems with 3 females, with statistically significant differences between classes (K-W test: $H(2, \mathrm{~N}=1,885)=$ $9.28 p=0.0096$ ).

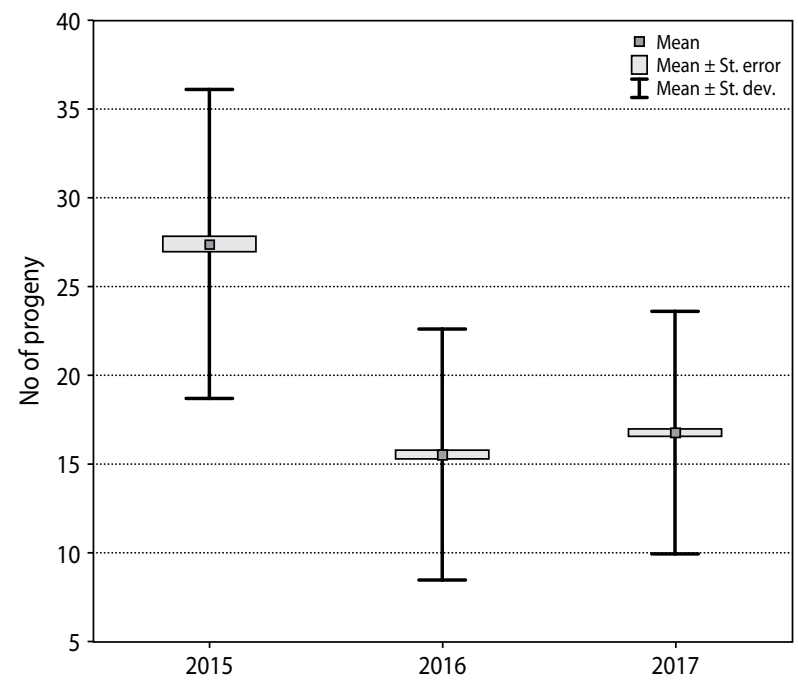

Figure 2. Average number of progeny per female in individual years

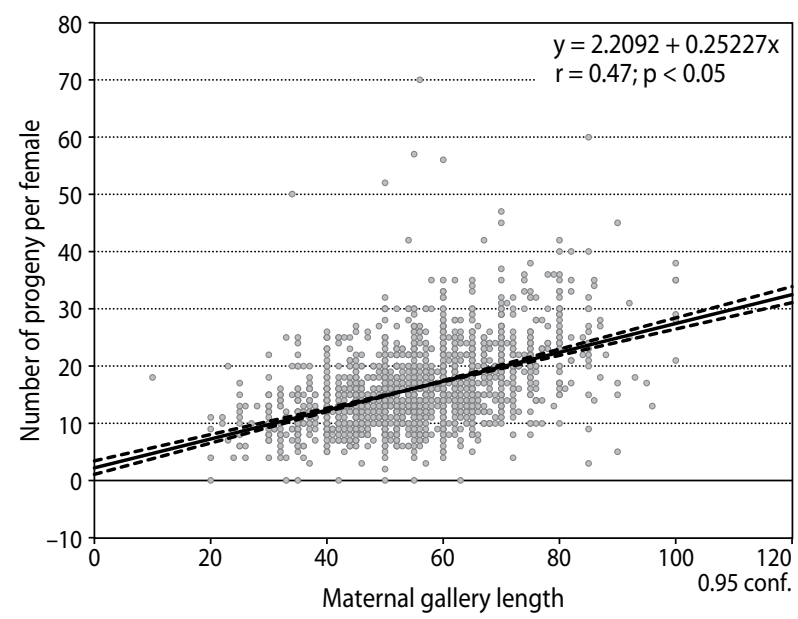

Figure 3. Relationship between the maternal gallery length and the number of progeny per female 
The number of progeny per 1 female, calculated using the data from 2016 to 2017 only $(\mathrm{n}=1,885$, mean $=$ $16.22 \pm 7.07)$ was weakly $(\mathrm{r}=0.47, p<0.05)$ correlated with the maternal gallery length (Fig. 3), with almost no $(\mathrm{r}=-0.07, p<0.05)$ relationship with the colonisation density.

A

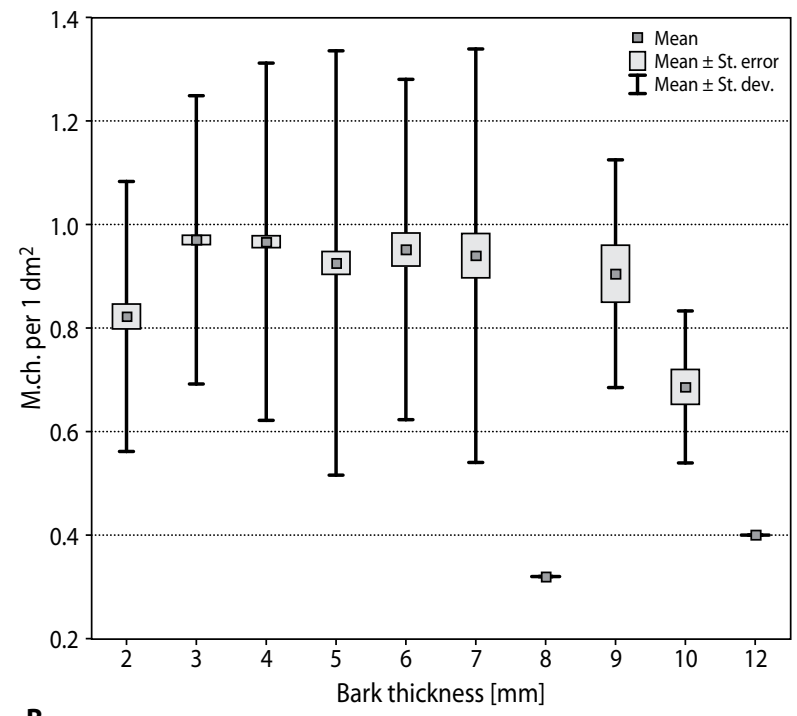

B

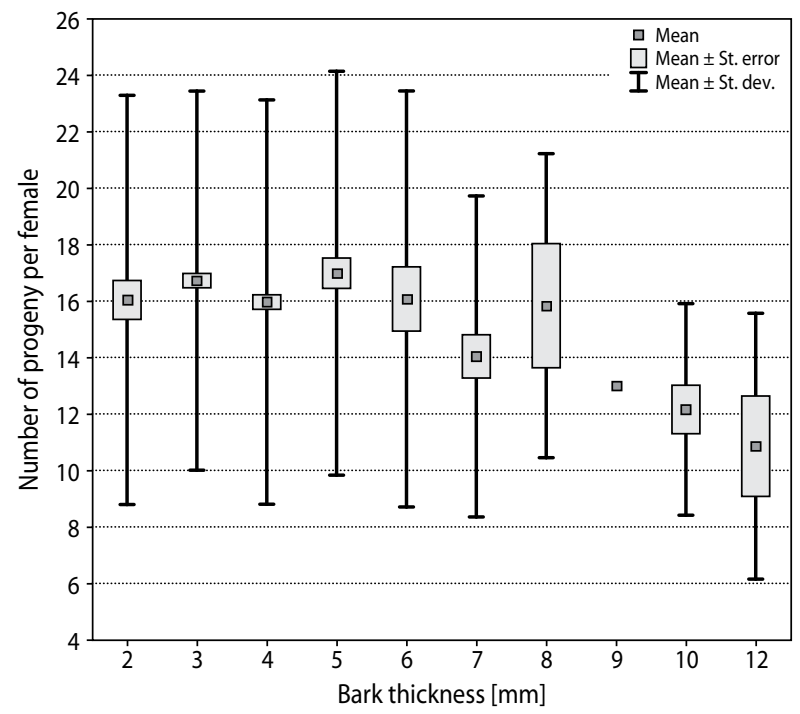

Figure 4. Infestation density (A) and number of progeny per female (B) in relation to bark thickness

The bark thickness in the range between 2 and 7 $\mathrm{mm}$ did not affect the infestation density; in the bark above $7 \mathrm{~mm}$, the density of mating chambers decreased
(Fig. 4A). Similar pattern concerns the reproduction success; however, the average number of progeny started to decrease in the bark above $8 \mathrm{~mm}$ (Fig. 4B). It is to be noted that amongst 304 bark samples, those with thickness of 3 and $4 \mathrm{~mm}$ absolutely dominated (102 and 99 samples, $66.1 \%$ in total), whilst only $12.8 \%$ of the samples had the thickness above $7-14 \mathrm{~mm}$ and $5.3 \%$ below $3 \mathrm{~mm}$. The distribution of measured galleries $(2,556$ in total) is even more biased to the classes of bark thickness of 3 and $4 \mathrm{~mm}(72.4 \%$ in total).

Taking into account the average density of females $\left(1.45\right.$ per $\left.\mathrm{dm}^{2}\right)$ and estimated mean progeny size (18.22 individuals per female), the emergence of about 2,640 new beetles can be expected from each 'statistical' metre square of the bark surface, which corresponds do $1-\mathrm{m}$ long section of spruce trunk of about $32 \mathrm{~cm}$ in diameter.

Very few parasitised I. typographus individuals was noted in 2015 ( 2 samples, 3-5\% in each), none in 2016 and a little more in 2017 (17 samples, 2-20\% each).

\section{Discussion}

The wind event in the Kościeliska Valley that occurred at the end of 2013 destroyed the spruce stands on large continuous area and affected the surrounding trees that survived the disaster. In the previous studies, usually additional wind damage occurred in the following years. Dispersion on new windthrowns, known from the other case studies, for example, in Gorce Mts. (Grodzki et al. 2006), did not occur in the case of Kościeliska Valley, as no new broken or fallen trees appeared in the years after the damage from 2013. Thus, the insect attack was focused on standing trees, which survived the wind but entered in deep stress because of another contributing factor - water deficiency started in 2015 and lasting in the next years. This factor strongly influenced the population dynamics in the next years.

The average gallery length in our study material recorded in subsequent years 2015-2017 $(5.5-5.7 \mathrm{~cm})$ was lower than that reported from recent bark beetle outbreak area in the Beskidy Mts. $-6.75 \mathrm{~cm}$ (Grodzki et al. 2014) - as well as previously from Šumava Mts. in the Czech Republic - 7.8 cm (Matoušek et al. 2012) - and from Bieszczady Mts. in Poland - $7.4 \mathrm{~cm}$ (Starzyk et al. 2000). On the other hand, the infestation densi- 
ties in Kościeliska Valley (0.79-0.86 mating chambers per $\mathrm{dm}^{2}$ ) were higher than those reported in the previous studies in Beskidy Mts. (0.57), Šumava Mts. (0.63) and Bieszczady Mts. (0.68), which can explain the differences found in maternal gallery length. The high share of females during all 3 years indicates that the I. typographus populations are in progressive outbreak phase (Lobinger 1996).

On the basis of the collected field data, we were trying to assess the reproduction abilities of I. typographus in favourable breeding conditions offered by the spruce stands damaged by the wind. Surprisingly, the effective reproduction success in the Kościeliska Valley (18.2 per female) was lower than that recorded from the populations at epidemic level in Šumava Mts. - 23.1 (Lukášová et al. 2012) - and Beskidy Mts. - 21.3 per female (Grodzki et al. 2014). When applying the simple regression model describing the relationship between the gallery length and number of progeny (see Fig. 3), as well as the other models based on the length of the maternal gallery proposed by Anderbrant (1990) and Grodzki et al. (2014), both observed and expected average values from Kościeliska Valley were lower than the average number calculated using those models (Fig. 5).

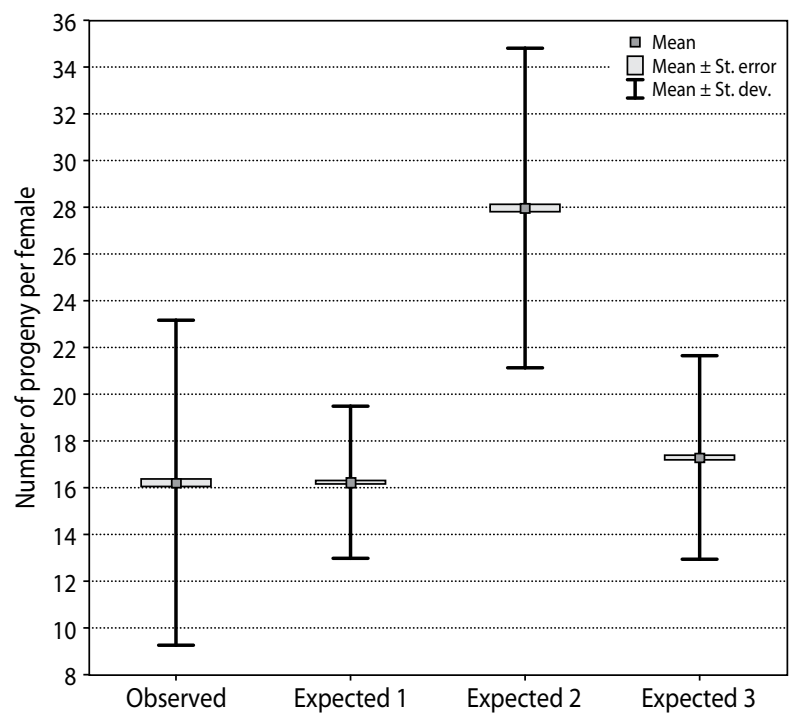

Fig. 5. Number of progeny per female calculated using three different models: expected 1, based on the actual correlation; expected 2, based on the regression model proposed by Anderbrant (1990); expected 3, based on the regression model proposed by Grodzki et al. (2014)
The estimation of expected number of progeny based on the maternal gallery length and resulting regression equation is not exact (Wilcoxon paired test - observed vs. expected 1: $\mathrm{N}=1,891, T=820,015.0$, $Z=3.134, p=0.0017$ ); however, both average values from the Tatra Mts. (observed: $16.22 \pm 6.95$; expected 1: $16.24 \pm 3.25$ ) are close to those (expected 3: $17.29 \pm 4.35)$ estimated using the equation from Beskidy Mts. (Grodzki et al. 2014) and far lower than the values (expected 2: $27.97 \pm 6.84$ ) resulting from the equation proposed by Anderbrant (1990) (Fig. 5). This confirms the previous finding that the data collected in the laboratory conditions by Anderbrant (1990) are overestimated in relation to those collected from the field in Beskidy (Grodzki et al. 2014), which seem to be closer to the real figures.

According to various published data, one I. typographus female can lay 30-80(100) eggs (Starzyk 2013), but laboratory tests revealed that the oviposition process and resulting fecundity is strongly dependent on temperature, reaching 23.3-23.6 eggs per female in optimal temperatures of $25-30^{\circ} \mathrm{C}$, but decreasing to 14.5 eggs in $20^{\circ} \mathrm{C}$ (Wermelinger and Seifert 1999). Lower reproduction success in the Kościeliska Valley (in comparison with the field data from the other localities) most probably results from less favourable thermal conditions on higher altitudes (cf. Grodzki and Gąsienica Fronek 2017) and relatively high infestation density on standing trees, necessary to overcome their defence mechanisms (Christiansen et al. 1987). This density, acting as an important factor that negatively affects the length of maternal galleries and oviposition (Anderbrant 1990, Weslien 1994, Grodzki et al. 2014), was much higher than 0.5 - the level optimal for I. typographus reproduction (Schopf and Köhler 1995). Nevertheless, our data did not demonstrate such relationship between the infestation density and the reproduction success, possibly because of more complex effect of intra-population mechanisms and environmental factors.

Schlyter and Zhang (1995) pointed out that the harems with more than 2 females reduce female reproductive success because of larval competition. Similar pattern was demonstrated in the present study, as the number of progeny was the lowest in case of gallery systems with 3 females. The high share of the gallery systems with 2 females indicates high reproduction potential of beetles attacking standing trees. On the other hand, the 
reproduction success, relatively high in the first year of the investigations (and also first year of the outbreak), collapsed in the next years to the level incomparable with previous studies, which is a phenomenon that is difficult to explain, especially taking into account the abundance of stressed trees, which is favourable for $I$. typographus reproduction (Grodzki et al. 2014; Grodzki and Gąsienica Fronek 2017). Possible reason of this collapse seems to result from long-lasting drought that can enhance the development of pre-imaginal stages, but - at the same time - decrease the quality of cambium, as moderate water stress (limiting growth but not photosynthesis) increases the production of carbonbased secondary metabolites (i.e. resin), thus reducing the suitability for the beetles (Christiansen and Bakke 1996). Lower reproduction success in 2016 and 2017 as compared with 2015 could also result from reduced survival rate of larvae hatched from eggs laid in maternal galleries, whose length did not differ between individual years. Reduced larvae survival could - in turn - result from less favourable development conditions in the breeding material of lower quality. The bark thickness did not affect the reproduction; however, most of the analysed gallery systems were established in optimal conditions concerning this parameter (Grünwald 1986).

Owing to relatively low density of galleries, the effect of intraspecific competition between larvae, suggested by DeJong and Grijpma (1986), cannot explain the pattern registered in the case of Kościeliska Valley. Also the impact of natural enemies, very low in analysed samples, should be excluded as possible reason of low reproduction success.

\section{Conclusion}

- The presented results indicate that reproduction abilities of I. typographus in the stands previously damaged by the wind in Kościeliska Valley were lower than those in the other areas, although - taking into account high infestation densities, low impact of natural enemies and the presence of stressed host trees - the outbreak potential of the bark beetle should be assessed as high.

- Contrarily to the other cited results, our data were collected exclusively from standing, living trees with still functioning (although sometimes reduced) defence mechanisms. Taking into account the described population features, very intense tree mortality (Grodzki and Gąsienica Fronek 2017) and mechanisms known from the other wind events (Grodzki and Guzik 2009), further development of the outbreak can be expected in this area.

\section{ACKNOWLEDGEMENTS AND SOURCE OF FUNDING}

Research was done within the project called 'Impact of forestry treatments in the spruce stands of the Tatra National Park on the occurrence of cambiophagus insects' accomplished in years 2015-2016 by the Tatra National Park and financed from the resources of the Polish State Forests Forest Fund.

\section{References}

Anderbrant O. 1990. Gallery construction and oviposition of the bark beetle Ips typographus (Coleoptera: Scolytidae) at different breeding densities. Ecological Entomology, 15, 1-8.

Christiansen E., Bakke A. 1996. Does drought really enhance Ips typographus epidemics? A Scandinavian perspective. In: Integrating Cultural Tactics into the Management of Bark Beetles and Reforestation Pests. Proceedings of the IUFRO Conference (eds.: J.-C. Grégoire, A.M. Liebhold, F.M. Stephen, K.R. Day, S.M. Salom). Vallombrosa 1-4 September 1996. USDA Forest Service General Technical Report NE-236, 163-171.

Christiansen E., Waring R.H., Berryman A.A. 1987. Resistance of conifers to bark beetle attack: searching for general relationships. Forest Ecology and Management, 22, 89-106.

DeJong M.C.M., Grijpma P. 1986. Competition between larvae of Ips typographus. Entomologia Experimentalis et Applicata, 41, 121-133.

Grodzki W. 2007. The use of pheromone traps for the monitoring of Ips typographus (L.) populations in selected national parks in the Carpathians (in Polish with English summary). Prace Instytutu Badawczego Leśnictwa, Rozprawy i monografie, 8, 1-127.

Grodzki W., Gąsienica Fronek W. 2017. Occurrence of Ips typographus (L.) after wind damage in the Kościeliska Valley of the Tatra National Park. Leśne Prace Badawcze / Forest Research Papers, 78 (2), 113-119. 
Grodzki W., Guzik M. 2009. Wiatro- i śniegołomy oraz gradacje kornika drukarza w Tatrzańskim Parku Narodowym na przestrzeni ostatnich 100 lat. Próba charakterystyki przestrzennej. Conference: Długookresowe zmiany w przyrodzie i użytkowaniu obszaru TPN (ed.: M. Guzik), Zakopane 21-22.05.2009, 33-46.

Grodzki W., Loch J., Armatys P. 2006. Występowanie kornika drukarza Ips typographus (L.) w uszkodzonych przez wiatr drzewostanach świerkowych masywu Kudłonia w Gorczańskim Parku Narodowym. Ochrona Beskidów Zachodnich, 1, 125-137.

Grodzki W., Starzyk J.R., Kosibowicz M. 2014. Variability of selected traits of Ips typographus (L.) (Col.: Scolytinae) populations in an area affected by bark beetle outbreak in Beskid Żywiecki (Western Carpathians, Poland). Folia Forestalia Polonica, Series A - Forestry, 56 (2), 79-92.

Grünwald M. 1986. Ecological segregation of bark beetles (Coleoptera, Scolytidae) of spruce. Journal of Applied Entomology, 101, 176-187.

Lobinger G. 1996. Variations in sex ratio during an outbreak of Ips typographus (Coleoptera: Scolytidae) in Southern Bavaria. Anzeiger für Schädlingskunde, Pflanzenschutz, Umweltschutz, 69, 51-53.

Lukášová K., Holuša J., Grucmanová Š. 2012. Reproductive performance and natural antagonists of univoltine population of Ips typographus (Coleoptera, Curculionidae, Scolytinae) at epidemic level: a study from Šumava Mountains, Central Europe. Beskydy, 5 (2), 153-162.

Matoušek P., Modlinger R., Holuša J., Turčáni M. 2012. Number of eggs laid by the spruce bark beetle Ips typographus (L.) (Coleoptera: Curculionidae: Scolytinae) on trap trees: influence of selected factors (in Czech with English summary). Zprávy Lesnického Výzkumu, 57 (2), 126-132

Schlyter F., Zhang Q.-H. 1995. Testing avian polygyny hypotheses in insects: harem size distribution and female egg gallery spacing in Ips bark beetles. Oikos, 76, 57-69.
Schopf R., Köhler U. 1995. Investigations on the population dynamics of spruce bark beetle in Bayerischer Wald National Park. In: 25 years towards natural forest (eds.: H. Biberlriether et al.). Passavia Druckerei GmbH, Passau, 88-109.

Starzyk J.R. 2013. Charakterystyka gatunku. In: Kornik drukarz Ips typographus (L.) i jego rola w ekosystemach leśnych (ed.: W. Grodzki). Centrum Informacyjne Lasów Państwowych, Warszawa, 17-36.

Starzyk J.R., Graboń K., Hałdaś E. 2000. Cambio- and xylophagous insects in spruce (Picea abies (L.) Karst.) stands of the Upper San River Valley in the Bieszczady Mountain National Park (Eastern Carpathians). Scientific Papers of the Agricultural University of Cracow, Forestry, 29, 57-73.

StatSoft, Inc. 2009. STATISTICA for Windows [Computer program manual]. Tulsa, OK: StatSoft, Inc., http://www.statsoft.com

Wermelinger B. 2002. Development and distribution of predators and parasitoids during two consecutive years of an Ips typographus (Col., Scolytidae) infestation. Journal of Applied Entomology, 126, 521-527.

Wermelinger B. 2004. Ecology and management of the spruce bark beetle Ips typographus - a review of recent research. Forest Ecology and Management, 202, 67-82.

Wermelinger B., Seifert M. 1999. Temperature-dependent reproduction of the spruce bark beetle Ips typographus, and analysis of the possible population growth. Ecological Entomology, 24, 103-110.

Weslien J. 1994. Interactions within and between species at different densities of the bark beetle Ips typographus and its predator Thanasimus formicarius. Entomologia Experimentalis et Applicata, 71, 133-143. 